\title{
Effect of HNT on mechanical and thermal properties of poly(lactic acid)/polypropylene carbonate blends*)
}

\author{
Intan Najwa Humaira Mohamed Haneef ${ }^{1)}$ (ORCHID ID: 0000-0003-0516-4525), \\ Yose Fachmi Buys ${ }^{2), 3), * *)}$ (0000-0002-4596-751X), Norhashimah Mohd Shaffiar ${ }^{1)}$ (0000-0001-7835-8764), \\ Sharifah Imihezri Syed Shaharuddin ${ }^{1)}$ (0000-0002-0333-5346), Abdul Malek Abdul Hamid") (0000-0002-9929-2597), \\ Mohd Faizul Mohd Sabri' ${ }^{2)}$ (0000-0001-8096-2709), Amalina Muhammad Afifi²) ${ }_{(0000-0003-3964-0171)}$
}

DOI: dx.doi.org/10.14314/polimery.2021.9.2

\begin{abstract}
In this work, the influence of halloysite nanotubes (HNTs) on the mechanical and thermal properties of the poly(lactic acid)/polypropylene carbonate (PLA/PPC 70/30) blend was studied. The HNT was incorporated into the PLA/PPC blend by melt mixing. It was found that addition of $2-6 \mathrm{wt} \%$ HNT successfully improved the tensile and flexural strength as well as the flexural and Young's moduli of PLA/PPC blend, due to the reinforcing effect. Although the elongation at break decreases with increasing HNT content, its value is much higher than that of pure PLA. Moreover, the addition of HNT did not affect the miscibility of PLA and PPC, since two glass transition temperatures were observed in the DSC thermograms. However, a higher content of HNT may improve the compatibility between PLA and PPC as evidenced by the lower difference between the glass transition temperature of PPC and PLA and reduced crystallinity resulting in higher tensile strength of nanocomposites.
\end{abstract}

Keywords: PLA, PPC, HNT, mechanical properties, thermal properties.

\section{Wpływ HNT na właściwości mechaniczne i termiczne mieszaniny poli(kwas mlekowy)/węglan polipropylenu}

Streszczenie: W pracy zbadano wpływ nanorurek haloizytowych (HNTs) na właściwości mechaniczne i termiczne mieszaniny poli(kwas mlekowy)/węglan polipropylenu (PLA/PPC 70/30). HNT wprowadzono do PLA/PPC poprzez mieszanie w stanie stopionym. Stwierdzono, że dodatek $2-6 \%$ mas. HNT skutecznie poprawił wytrzymałość na rozciąganie i zginanie, a także moduł sprężystości przy zginaniu i moduł Younga mieszaniny PLA/PPC, jako efekt wzmacniający. Pomimo, że wydłużenie przy zerwaniu zmniejsza się wraz ze wzrostem zawartości HNT, to jego wartość jest znacznie większa niż w przypadku czystego PLA. Nie stwierdzono wpływu HNT na mieszalność PLA i PPC, ponieważ na termogramach DSC zaobserwowano dwie temperatury zeszklenia. Jednak większa zawartość HNT może poprawić mieszalność PLA i PPC, o czym świadczy mniejsza różnica między temperaturą zeszklenia PPC i PLA oraz mniejszy stopień krystaliczności, co skutkuje wiekszą wytrzymałościa na rozciaganie nanokompozytów.

Słowa kluczowe: PLA, PPC, HNT, właściwości mechaniczne, właściwości termiczne.

Poly(lactic acid) (PLA) has rapidly become a subject of interest in various areas such as packaging [1] and biomedical applications [2]. It offers biodegradability, biocompatibility, processability, and is eco-friendly com- pared to other polymers, available in the industry [3]. It also possesses other unique characteristics, such as excellent transparency, high mechanical strength, it is less harmful, and has an excellent barrier properties [4]. PLA,

\footnotetext{
1) Department of Manufacturing and Materials Engineering, Kulliyyah of Engineering, International Islamic University Malaysia, 53100, Selangor, Malaysia.

2) Department of Mechanical Engineering, Faculty of Engineering, University of Malaya, 50603 Kuala Lumpur, Federal Territory of Kuala Lumpur, Malaysia.

3) Department of Mechanical Engineering, Faculty of Industrial Technology, Universitas Pertamina, Jakarta 12220, Indonesia.

*) Material contained in this article was presented at the 1st Malaysia International Conference on Nanotechnology \& Catalysis (MICNC 2021), 1-3 September 2021, Malaya, Malaysia.

**) Author for correspondence: yose.fachmi@universitaspertamina.ac.id
} 
thanks to its biodegradability, is a promising replacement for the non-degradable engineering polymers such as polyethylene terephthalate (PET) [5].

Malinconico et al. reported many PLA interests in textile, agriculture, packaging, medical and pharmaceutical industry [6]. However, PLA has some disadvantages, and one of its significant problems is a lack of toughness. According to Farah et al., although the mechanical strength of PLA is equal to PET, it has a very low elongation of less than $10 \%$ [7]. Furthermore, its brittle characteristic is one of the problems that hinder PLA in areas that require a flexible application at a higher stress level. Cakir et al. suggested the using of an additive to decrease its brittleness [8].

Works on diminishing of PLA brittleness have been issued for a couple of years, and it appears to be still an area of active research [9-12]. Recently, the authors have restricted the brittleness of PLA with polypropylene carbonate (PPC) $[13,14]$. As a result, the elongation of neat PLA was greatly enhanced with the addition of $30 \mathrm{wt} \%$ PPC. However, there is a significant decrease in the tensile strength. This problem is not a new one and has been partly addressed by the previous study by Zou et al. [15]. Hence, maintaining the balance between high tensile strength and high elongation of PLA blends/composites is a difficult task.

Some researchers have suggested a few ways on maintaining a balance between tensile strength and elongation of the PLA/PPC blends, such as the addition of compatibilizer [16-19] and nanoparticles such as coreshell starch [20] and multi-walled carbon nanotubes (MWCNT) [21, 22]. For example, Sun et al. used a compatibilizer in PLA/PPC blends and successfully noted the improvement in mechanical properties [16]. Meanwhile, Yao et al. found that the addition of maleic anhydride (MA) to PLA / PPC blends significantly improved their elongation without losing tensile strength [18].

Halloysite nanotubes (HNT) have recently become a prevalent subject of research [23-25]. It consists of a tubular size varying from $500-1000 \mathrm{~nm}$ in length and $15-100 \mathrm{~nm}$ in inner diameter. HNT is considered to be the most suitable reinforcing agent compared to other nanotubes because it is biocompatible to the human body [26]. Furthermore, many researchers have proved that HNT could improve the mechanical properties of other polymers such as polycaprolactone/polylactic acid, polyethylene terephthalate/ polypropylene nanocomposites, polyetherimide/silicone rubber, and other PLA nanocomposites [27-30]. For example, Kelnar et al. enhanced the blends' tensile strength at a relatively low content of HNT [27].

Hence, the authors believe that adding HNT to PLA/PPC blends can improve their mechanical properties.To the best of the authors knowledge, no systematic study of PLA/PPC/HNT nanocomposite has been reported yet. Therefore, HNT was used as a reinforcing agent for PLA/PPC 70/30 blend in order to improve the mechanical properties.The effect of HNT content on the mechanical and thermal properties of PLA/PPC/HNT nanocomposites was investigated and critically discussed in this report.

\section{EXPERIMENTAL PART}

\section{Materials and preparation of samples}

PLA grade 3052D with a molecular weight of $116,000 \mathrm{~g} / \mathrm{mol}$ was purchased from Nature Works, LLC (USA). PPC with a grade of QPAC 40 and molecular weight of approximately $100,000-300,000 \mathrm{~g} / \mathrm{mol}$ was obtained from Empower Materials, LLC (USA). HNT grade NN-HNT200 with a length range between $500 \mathrm{~nm}$ to over $1.2 \mu \mathrm{m}$ was obtained from Natural Nano, Inc (USA).

PLA is still in its continuous phase when it is melt mixed with less than $30 \mathrm{wt} \%$ of PPC [18]. Since this research aims to obtain PLA nanocomposites with balance in mechanical properties, a 70/30 PLA/PPC blend was selected in this study to be incorporated with HNTs. Before blending, PLA and HNTs were dried at $70^{\circ} \mathrm{C}$ while PPC was dried at $40^{\circ} \mathrm{C}$ in an oven for at least 24 hours to remove moisture. A specific amount of $\operatorname{HNT}(2,4$, and $6 \mathrm{wt} \%$ ) was incorporated into PLA/PPC 70/30 blend at $180^{\circ} \mathrm{C}$ at a rotation of $50 \mathrm{rpm}$ for 10 minutes using an internal mixer (Haake Polylab System Thermo). After blending, the PLA/PPC/HNT nanocomposites were crushed into smaller pieces using a crusher machine model HITOP, M SY-20. The samples for testing mechanical properties were obtained by compression molding at $185^{\circ} \mathrm{C}$ using the hot- press machine. The pre-heat time was 7 minutes and a pressing time 3 minutes.

\section{Methods}

The tensile mechanical properties of PLA/PPC/HNT nanocomposites were investigated according to ASTM D638 standards. Samples were tested at a $5 \mathrm{~mm} / \mathrm{min}$ crosshead speed using the Universal Testing Machine model PFG5K (Shimadzu Instrument, Japan). At least five samples of each composition were tested, and average results were reported.

The flexural properties were conducted at a crosshead speed of $5 \mathrm{~mm} / \mathrm{min}$ according to ASTM D790 using the universal testing machine, model PFG5K from Shimadzu Instrument. The test was conducted to find the samples' flexural strength and flexural modulus with a 3 points bending method. At least five specimens with a dimension of $3.2 \times 12.7 \times 125 \mathrm{~mm}$ were tested, and the average results were calculated.

The impact strength was performed using the Charpy impact test machine (Dynisco Polymer test) with the power of the pendulum set to $75 \mathrm{~J}$ at room temperature according to ASTM D256. The notches on each specimen were made using a notch cutter before testing. 
The thermal properties were conducted using the differential scanning calorimetry (DSC) machine model Mettler Toledo with a $20 \mathrm{ml} / \mathrm{min}$ nitrogen flow rate. The samples were dried at $60^{\circ} \mathrm{C}$ for $24 \mathrm{~h}$ before testing. The specimens weighed between 8 and $12 \mathrm{mg}$ were crimped in the aluminum crucible with an empty crimped aluminum pan used as the reference. The samples were heated from $20^{\circ} \mathrm{C}$ to $220^{\circ} \mathrm{C}$ at a rate of $30^{\circ} \mathrm{C} / \mathrm{min}$ to remove the thermal history and then held isothermally for $10 \mathrm{~min}$. Next, the samples were cooled down to $-30^{\circ} \mathrm{C}$ at a rate of $30^{\circ} \mathrm{C} / \mathrm{min}$. Finally, the samples were heated again from $-30^{\circ} \mathrm{C}$ to $220^{\circ} \mathrm{C}$ at a rate of $10^{\circ} \mathrm{C} / \mathrm{min}$. The crystallinity, glass transition temperature and melting temperature of each sample were recorded and analyzed. The crystallinity $X_{c}$ of the samples were calculated based on Equation 1 $[31,32]$.

$$
X_{c}=\frac{\Delta H_{m}^{\circ}}{\left(1-\omega_{t}\right) \Delta H_{m}^{\circ}} \cdot 100
$$

where: $\Delta H_{m}^{\circ}$ stands for the theoretical specific melting heat of $100 \%$ crystalline sample and $\omega_{t}$ represents the weight fraction of added HNTs. For PLA, $\Delta H_{m}^{\circ}$ value was taken as $93 \mathrm{~J} / \mathrm{g}[33,34]$.

\section{RESULTS AND DISCUSSION}

\section{Tensile properies}

Figure 1 illustrates the tensile strength and Young's modulus of PLA/PPC 70/30 blend with different HNTs content. As shown in Fig. 1, the tensile strength of PLA/PPC blend is $32 \mathrm{MPa}$ with Young's modulus 1.26 GPa. The tensile strength and Young's modulus of PLA/PPC/HNTs nanocomposites increase with increasing HNTs content to $4 \mathrm{wt} \%$. However, a further increase in the HNT content causes a visible decrease in the tensile strength from 41 to $37 \mathrm{MPa}$. Simultaneously, Young's modulus also significantly decreases from 1.42 to $1.36 \mathrm{GPa}$. However, both values are still higher compare to the blend without HNT.

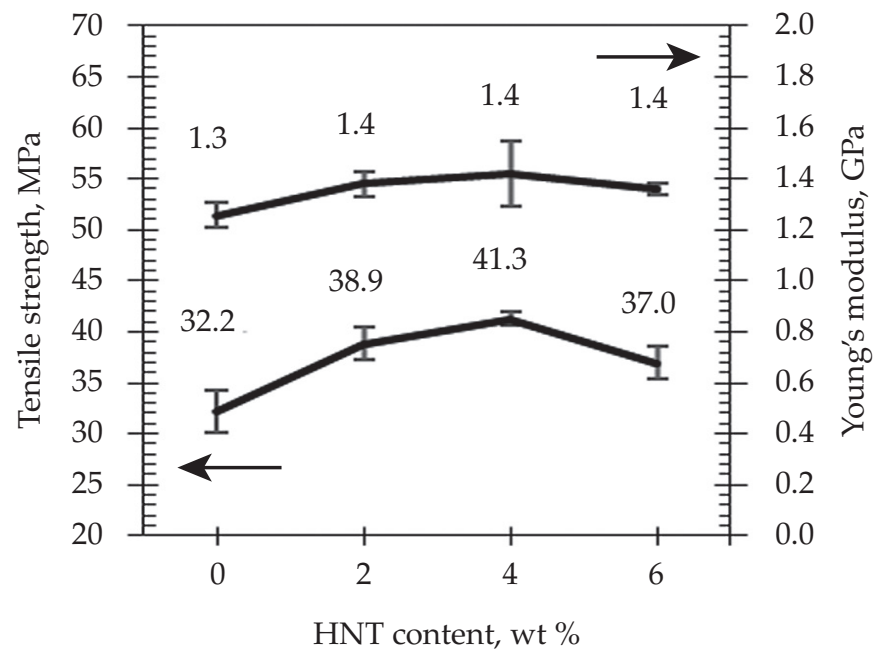

Fig. 1 Tensile strength and Young's modulus of PLA/PPC 70/30 blend with different HNT content

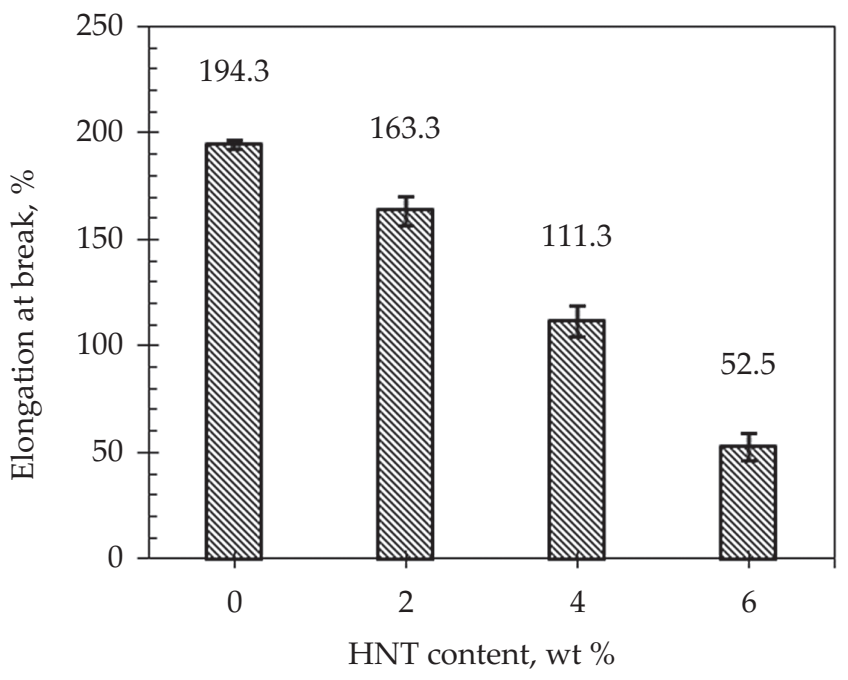

Fig. 2. Elongation at break of PLA/PPC blend with different HNT content

Contrary to the tensile strength and Young's modulus of PLA/PPC/HNT nanocomposites shown in Figure 1, the elongation at break gradually decreases with increasing HNT's content (Fig. 2). However, the elongation of the composites is much higher than the neat PLA. This behavior was expected because HNT acts as a reinforcing agent and improves the PLA/PPC's stiffness, resulting in a lower elongation at break. A significant decrease in elongation (about 73\%) was observed at 6 wt \% HNT content, which can be explained by nanofiller agglomeration, as reported by Eryildiz et al. [35].

Figure 3 illustrates the stress-strain curves of the nanocomposites. The PLA/PPC blend has the lowest tensile strength of $32 \mathrm{MPa}$ with the highest elongation at break of around $190 \%$. The tensile strength increases to $39 \mathrm{MPa}$ with the incorporation of $4 \mathrm{wt} \%$ HNT. The elongation at break, however, gradually decreases with the increase of HNT. Nevertheless, the decrease of elongation at break does not affect the mechanical properties since the value is still much higher than neat PLA reported in previous research [13].

\section{Flexural properties}

Figure 4 represents the flexural strength and flexural modulus of PLA/PPC blend with different amounts of HNT. Initially, the flexural modulus decreases from 1.70 to $1.46 \mathrm{GPa}$ when $2 \mathrm{wt} \%$ of HNT is added. However, when the HNT content increases to $4 \mathrm{wt} \%$, the flexural modulus increases to $1.76 \mathrm{GPa}$. On the other hand, the flexural strength increases steadily from 48 to $55 \mathrm{MPa}$ as the amount of HNT increases to $4 \mathrm{wt} \%$. However, there is a slight decrease in flexural strength and flexural modulus from $55 \mathrm{MPa}$ and $1.76 \mathrm{GPa}$ to $54 \mathrm{MPa}$ and $1.74 \mathrm{GPa}$ as the HNT increases from 4 to $6 \mathrm{wt} \%$. It should be emphasized that the values are still much higher compared to the PLA/PPC blend. 


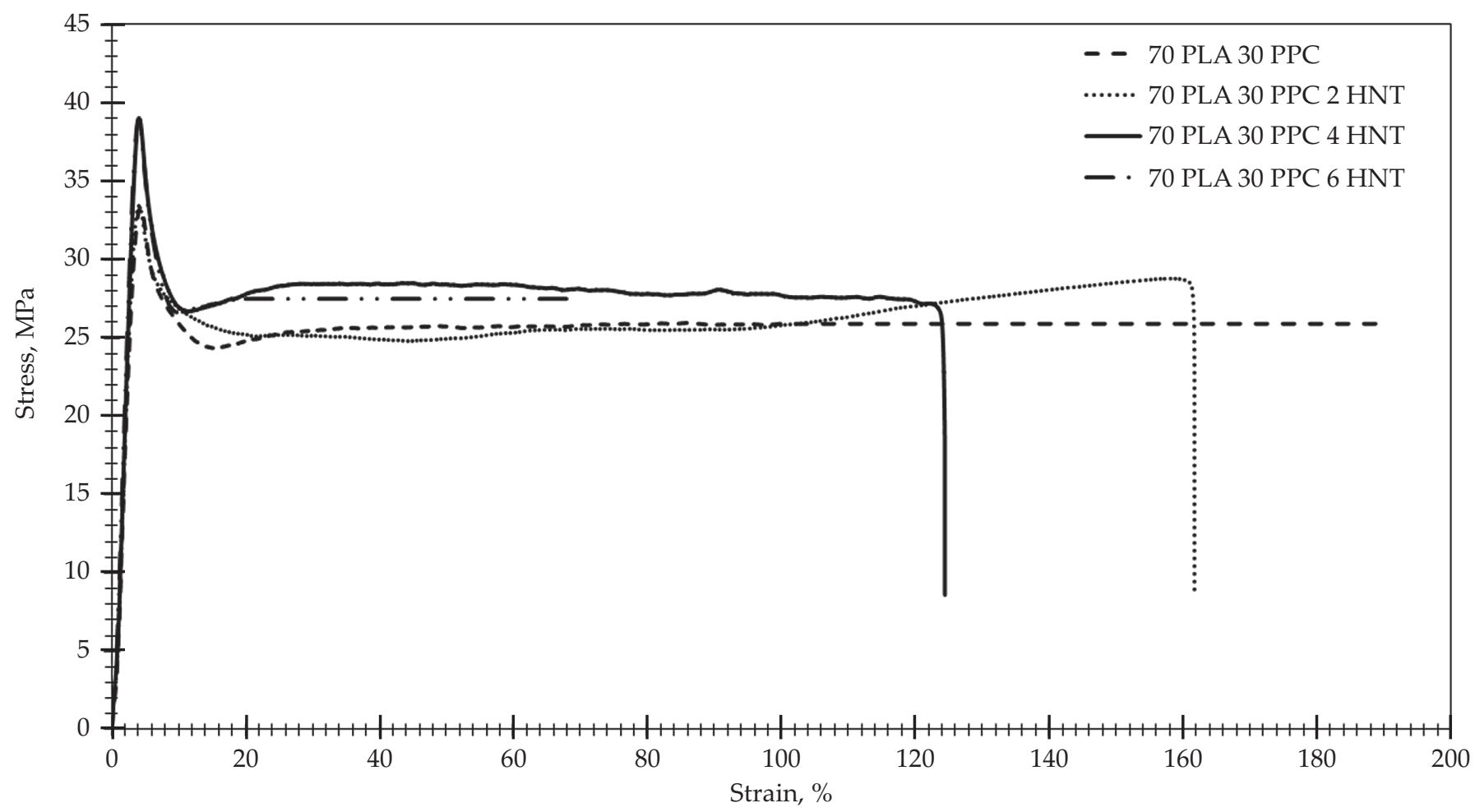

Fig. 3. Stress-strain curves of PLA/PPC blend with different HNT content

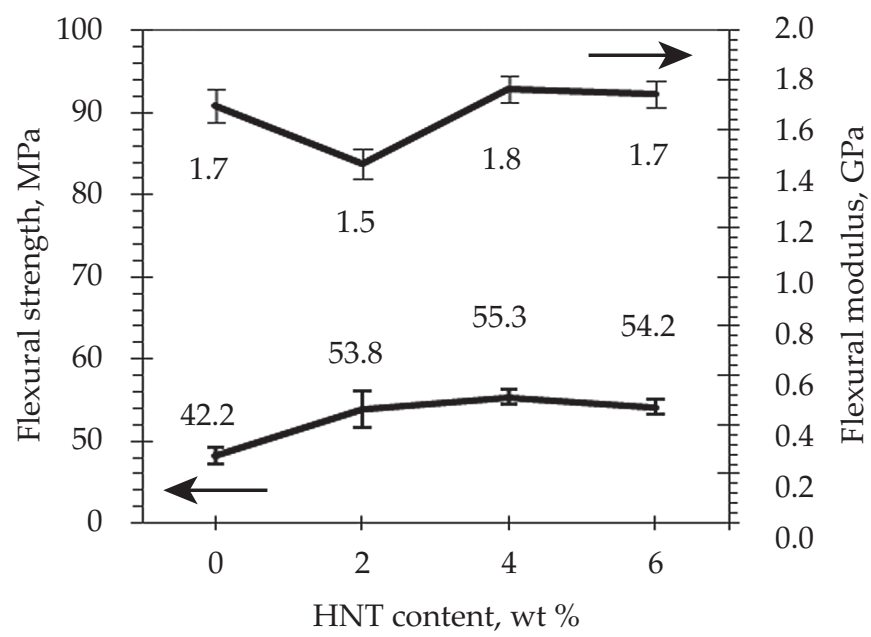

Fig. 4. Flexural strength and modulus of 70/30 PLA/PPC with different HNT content

\section{Impact test}

Figure 5 displays the impact strength of PLA/PPC with different HNT content. As can be seen there are no significant differences in the impact strength as HNT content increases to $4 \mathrm{wt} \%$. However, the impact strength decreases from 8.7 to $7.7 \mathrm{~kJ} / \mathrm{m}^{2}$ as the HNT content increases from 4 to $6 \mathrm{wt} \%$, and is lower than without the addition of HNT.

The results show a strengthening effect of HNT due to better tensile and flexural strength and modulus of the PLA/PPC/HNT composites. It is believed that the enhancement of mechanical properties is due to the fine dispersion of intercalated HNT within PLA/PPC

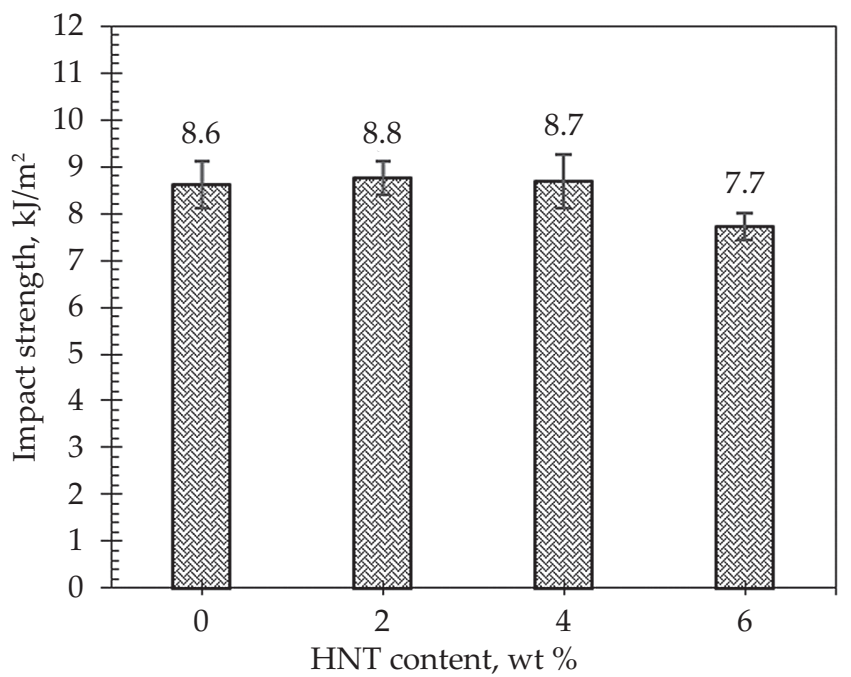

Fig. 5. Impact strength of PLA/PPC 70/30 with different HNT content

matrix. A similar trend is also reported by Erpek et al. for PLA/HNT composites [36]. Moreover, HNT has a tubular nanostructure with a large aspect ratio, consists of an alumine network at the inner surface and a siloxane network on the outer surface. It is believed that during melt-mixing, the polymer chain diffuse from the bulk polymers melt into the interlayer of these nanotubes, resulting in a well-ordered multilayer with alternating polymer, siloxane, and alumine network layer of HNT. This behavior is in accordance with the theory of polymer blends with nanocomposites reported in the literature [37].

Meanwhile, for the elongation at break of PLA/PPC/HNT nanocomposites, there is a noticeable 
T a b l e 1. Mechanical properties of neat PLA and PLA/PPC blend

\begin{tabular}{c|c|c|c|c|c|c}
\hline Sample & $\begin{array}{c}\text { Tensile } \\
\text { strength, MPa }\end{array}$ & $\begin{array}{c}\text { Tensile } \\
\text { modulus, GPa }\end{array}$ & $\begin{array}{c}\text { Elongation at } \\
\text { break, } \%\end{array}$ & $\begin{array}{c}\text { Flexural } \\
\text { strength, MPa }\end{array}$ & $\begin{array}{c}\text { Flexural } \\
\text { modulus, GPa }\end{array}$ & $\begin{array}{c}\text { Impact } \\
\text { strength, } \mathrm{kJ} / \mathrm{m}^{2}\end{array}$ \\
\hline Neat PLA & $68 \pm 1$ & $2.23 \pm 0.06$ & $3.8 \pm 0.4$ & $64 \pm 5$ & $2.33 \pm 0.01$ & $5.5 \pm 0.3$ \\
PLA/PPC 70/30 & $32 \pm 3$ & $1.26 \pm 0.02$ & $194 \pm 1$ & $48 \pm 2$ & $1.70 \pm 0.02$ & $8.6 \pm 0.04$ \\
\hline
\end{tabular}

T a b l e 2. Thermal properties of PLA/PPC/HNT nanocomposites determined by the DSC method

\begin{tabular}{c|c|c|c|c|c|c|c|c|c}
\hline PLA/PPC/ HNT & $T_{g}$ PPC, ${ }^{\circ} \mathrm{C}$ & $T_{g}$ PLA, ${ }^{\circ} \mathrm{C}$ & $\Delta T_{g^{\prime}}{ }^{\circ} \mathrm{C}$ & $T_{c^{\prime}}{ }^{\circ} \mathrm{C}$ & $T_{m 1^{\prime}}{ }^{\circ} \mathrm{C}$ & $T_{m 2^{\prime}}{ }^{\circ} \mathrm{C}$ & $\Delta H_{c^{\prime}} \mathrm{J} / \mathrm{g}$ & $\Delta H_{m^{\prime}} \mathrm{J} / \mathrm{g}$ & $X_{c^{\prime}} \%$ \\
\hline $100 / 0 / 0$ & - & 48 & - & 111 & 145 & 151 & 17.29 & 15.44 & 16.60 \\
$70 / 30 / 0$ & 29 & 54 & 25 & 106 & 146 & 154 & 17.20 & 18.12 & 19.50 \\
$70 / 30 / 2$ & 23 & 47 & 24 & 103 & 143 & 152 & 21.05 & 17.35 & 19.04 \\
$70 / 30 / 4$ & 25 & 49 & 24 & 104 & 144 & 153 & 15.44 & 16.64 & 18.64 \\
$70 / 30 / 6$ & 32 & 55 & 23 & 117 & - & 152 & 14.65 & 14.86 & 17.00 \\
\hline
\end{tabular}

reduction as a function of HNT. To support the current investigation, the authors performed mechanical tests on neat PLA. As shown in Table 1, neat PLA has a low elongation at break of only about $3 \%$ with tensile strength of $68 \mathrm{MPa}$. The addition of $30 \mathrm{wt} \%$ of PPC changed neat PLA from brittle to ductile. However, the tensile strength decreased by $53 \%$ of its initial value (neat PLA). An addition of only $2 \mathrm{wt} \%$. HNT increased the tensile strength by about $28 \%$. Although the elongation at break decreased with the addition of HNT, the values were still much higher compared to neat PLA.

Interestingly, an overloading amount of HNT could reduce PLA/PPC blend properties. Deterioration of tensile and flexural properties as well as in impact strength at HNT higher content (6 wt \%) is illustrated in Figs. 1, 4 and 5. It is believed that with a high content of HNT, aggregates may be formed, leading to deterioration of the mechanical properties. Further structural research is required to confirm this conclusion (SEM, TEM).

\section{Thermal properties}

The thermal behavior of PLA/PPC/HNT nanocomposites was determined by DSC method. The glass transition temperature $\left(T_{g}\right)$, crystallization temperature $\left(T_{c}\right)$, melting temperature $\left(T_{m}\right)$, cold crystallization enthalpy $\left(\Delta H_{c}\right)$, the heat of melting $\left(\Delta H_{m}\right)$, and crystallization degree of PLA/PPC blend reinforced with different HNT amounts is presented in Table 2. Figure 6 illustrates the DSC thermograms of PLA/PPC/HNT nanocomposites.

Based on the observation, two $T_{q}$ in the PLA/PPC blend show that the blend is partially miscible. The addition of $2 \mathrm{wt} \%$ of HNT has practically no effect on the miscibility of PLA/PPC, as the nanocomposite still has two $T_{g}$. When the amount of HNT increases to $6 \mathrm{wt} \%$, the $T_{g}$ of PPC and the $T_{g}$ of PLA tend to move towards each other, while the crystallinity continues to decline. Therefore, it is believed that higher HNT content may result in partial miscibility of PLA and PPC, which is associated with higher tensile strength of nanocomposites shown in Figs. 1 and 3. The incorporation of $2 \mathrm{wt} \%$ of HNT in PLA/PPC blend resulted in a $T_{g}$ decrease, from $29^{\circ} \mathrm{C}$ and $54^{\circ} \mathrm{C}$ to $23^{\circ} \mathrm{C}$ and $47^{\circ} \mathrm{C}$, respectively. The $T_{g}$ of the PLA/PPC/HNT increased from $23^{\circ} \mathrm{C}$ and $47^{\circ} \mathrm{C}$ to $32^{\circ} \mathrm{C}$ and $55^{\circ} \mathrm{C}$ when the amount of HNT was up to $6 \mathrm{wt} \%$.

The same trend was also seen for the $T_{c^{\prime}}$ which increased from $106^{\circ} \mathrm{C}$ to $117^{\circ} \mathrm{C}$. This result was in contrast with Kaygusuz and Kaynak [33]. The decreased $T_{c}$ showed that HNT acted as a nucleating agent, which improved the polymer flexibility. In this case, adding of HNT resulted in an apparent shift of $T_{c}$ from $103^{\circ} \mathrm{C}$ to $117^{\circ} \mathrm{C}$. Therefore, it can be concluded that the increase of HNT restricted the blend's molecular entanglement, thus reducing PLA/PPC flexibility explained by Fig. 3. The higher the amount of HNT incorporated into PLA/PPC, the lower elongation of the PLA/PPC/HNT nanocomposites.

Double $T_{m}$ were recorded for all nanocomposites. The double melting temperature refers to the melt recrystallization mechanism of PLA during the second heating cycle. In the process of this heating, the less perfect PLA crystals have gained enough time to melt and formed more perfect crystals. Later, it melted again creating a higher melting temperature [38]. The incorporation of

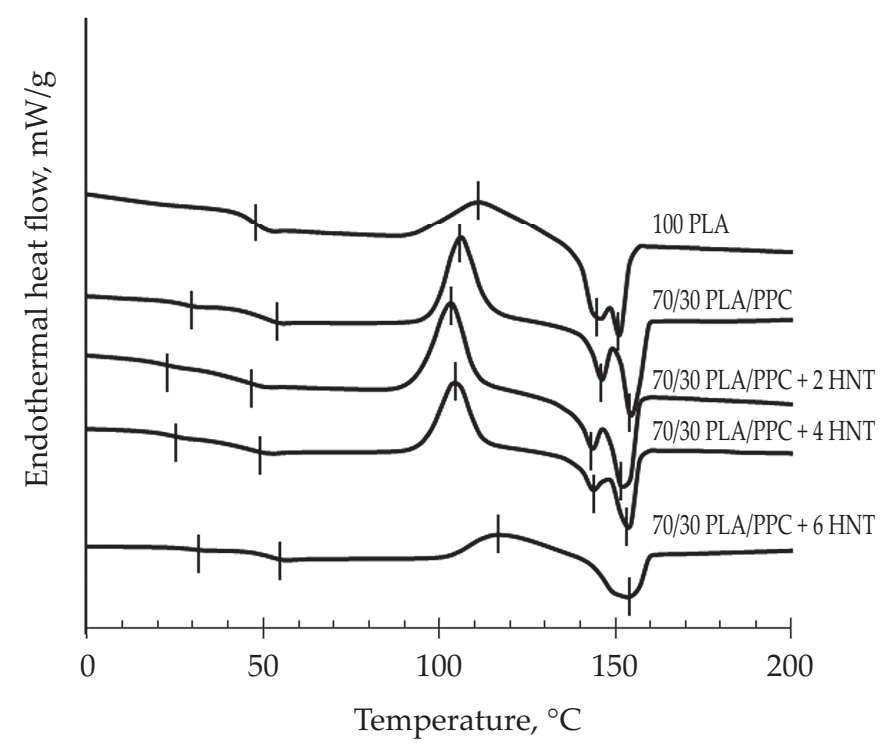

Fig. 6. DCS thermograms of PLA/PPC/HNT nanocomposites 
$6 \mathrm{wt} \%$ HNTs resulted in single $T_{m}$. There is only a slight decrease in $T_{m}$ as the amount of HNT increases. This shows that the HNT amount does not significantly influence the $T_{m}$ of nanocomposites. Meanwhile, the crystallinity of the nanocomposites gradually decreased as the HNT amount increased. This may be due to rigid filler HNT, which disrupts the PLA/PPC matrix's continuity that causes a decreased flexibility [38].

\section{CONCLUSIONS}

The new reinforced PLA/PPC/HNT nanocomposites differing in HNT content ( $0 \mathrm{wt} \%$ to $6 \mathrm{wt} \%$ ) were obtained by melt mixing. HNT could improve the tensile, impact, and flexural strength of PLA/PPC 70/30 blend. Besides, the stiffness was remarkably improved as Young's modulus of the nanocomposites increased with increasing HNT content. Thermal properties determined by DSC method showed that HNT did not significantly affect the phase transition temperatures of nanocomposites $\left(T_{g}, T_{c}\right.$ and $\left.T_{m}\right)$. In addition, HNT limited the flexibility of PLA/PPC/HNT nanocomposites due to the greater stiffness that limited the mobility of the PLA/PPC chains. The lower flexibility is associated with a gradual decrease in crystallinity, suggesting better miscibility.

\section{ACKNOWLEDGMENT}

The authors would like to thank the Faculty of Engineering, University of Malaya (Grant No.: GPF047A-2019) and the Department of Manufacturing and Materials Engineering, Kulliyyah of Engineering IIUM, for the research support.

\section{REFERENCES}

[1] Palai B., Mohanty S., Nayak S. K.: Polymer Testing 2019, 83, 106130.

https://doi.org/10.1016/j.polymertesting.2019.106130

[2] Alam F., Shukla V.R., Varadarajan K.M., Kumar S.: Journal of the Mechanical Behavior of Biomedical Materials 2020, 103, 103576.

https://doi.org/10.1016/j.jmbbm.2019.103576

[3] Singh S., Prakash C., Singh M. et al.: „Poly-lactic-Acid: Potential Material for Bio-printing Applications", (editor Prakash C. et al.) Biomanufacturing. Springer, Cham, 2019, pg. 69. https://doi.org/10.1007/978-3-030-13951-3_3

[4] Jamshidian M., Tehrany E. A., Imran M. et al.: Comprehensive Reviews in Food Science and Food Safety 2010, 9, 552. https://doi.org/10.1111/j.1541-4337.2010.00126.x

[5] Nagarajan V., Mohanty A. K., Misra M.: ACS Sustainable Chemistry E Engineering 2016, 4, 2899. https://doi.org/10.1021/acssuschemeng.6b00321

[6] Malinconico M., Vink E. T.H., Cain A.: “Applications of Poly(lactic Acid) in Commodities and Specialties" in "Advance in Polymer Science" Springer International Publishing AG. 2018, 35. https://doi.org/10.1007/12_2017_29

[7] Farah S., Anderson D.G., Langer R.: Advanced Drug Delivery Reviews 2016, 107, 367.

https://doi.org/10.1016/j.addr.2016.06.012

[8] Cakir S., Aycicek M., Akinci A.: Materials Science: Advance Composite Materials 2018, 2, 1. http://dx.doi.org/10.18063/msacm.v2i1.607

[9] Jing X., Mi H.Y., Peng X.F., Turng L.S.: Polymer Engineering $\mathcal{E}$ Science 2015, 55, 70. https://doi.org/10.1002/pen.23873

[10] Yang Y., Chen Y., Leng F. et al.: Applied Sciences 2017, 7, 1215. https://doi.org/10.3390/app7121215

[11] Don T.-M., Li T. -S., Lai W. -C.: Polymer Degradation and Stability 2019, 162, 55.

https://doi.org/10.1016/j.polymdegradstab.2019.01.035

[12] Ramlee N.A., Tominaga Y.: Polymer 2019, 166, 44. http://dx.doi.org/10.1016/j.polymer.2019.01.043

[13] Haneef I.N.H.M., Buys Y.F., Shaffiar N.M., Shaharuddin S.I.S. et al.: Materials Today: Proceedings, 2019, 17, 534.

https://doi.org/10.1016/j.matpr.2019.06.332

[14] Haneef I.N.H.M., Buys Y.F., Shaffiar N.M., Haris N.A. et al.: Polymer Engineering and Science 2020, 60, 2876. https://doi.org/10.1002/pen.25519

[15] Zou W., Chen R., Zhang H., Qu J.:AIP Conference Proceeding. 2017, 1713, 050003. https://doi.org/10.1063/1.4942279

[16] Sun Q., Mekonnen T., Misra M., Mohanty A. K.: Journal of Polymers and the Environment 2015, 24, 23. https://doi.org/10.1007/s10924-015-0743-6

[17] Qin S. X., Yu C. X., Chen X. Y., Zhou H. P. et al.: Chinese Journal of Polymer Science 2018, 36, 783. https://doi.org/10.1007/s10118-018-2065-3

[18] Yao M., Deng H., Mai F., Wang K. et al.: EXPRESS Polymer Letters 2011, 5, 937.

http://dx.doi.org/10.3144/expresspolymlett.2011.92

[19] Wang Z., Zhang M., Liu Z., Zhang S. et al.: Journal of Applied Polymer Science 2017, 135, 46009. https://doi.org/10.1002/app.46009

[20] Dong X., Liu L., Wang Y., Li T. et al.: Carbohydrate Polymers 2021, 254, 117321. https://doi.org/10.1016/j.carbpol.2020.117321

[21] Park D. H., Kim T. G., Lee Y. K., Kim W. N.: Journal of Materials Science 2012, 48, 481. http://dx.doi.org/10.1007/s10853-012-6762-y

[22] Yang G., Geng C., Su J., Yao W. et al.: Composites Science and Technology 2013, 87, 196. https://doi.org/10.1016/j.compscitech.2013.08.010

[23] Saif M.J., Asif H.M., Naveed M.: Journal of Chilean Chemical Society 2018, 63, 4109. http://dx.doi.org/10.4067/s0717-97072018000304109

[24] Kausar A.: Polymer-Plastics Technology and Engineering 2017, 57, 548. https://doi.org/10.1080/03602559.2017.1329436

[25] Santos A.C., Ferreira C., Veiga F., Ribeiro A.J. et al.: Advances in Colloid and Interface Science 2018, 257, 58. 
https://doi.org/10.1016/j.cis.2018.05.007

[26] Wu Y., Zhang Y., Ju J., Yan H. et al.: Polymers 2019, 11, 987.

https://doi.org/10.3390/polym11060987

[27] Kelnar I., Kratochvíl J., Fortelny I., Kaprálková L. et al.: EXPRESS Polymer Letters 2016, 10, 381.

http://dx.doi.org/10.3144/expresspolymlett.2016.36

[28] Inuwa I., Razak N.C., Arjmandi R., Hassan A.: Polymer Composites, 2018, 39, 1554. http://dx.doi.org/10.1002/pc.24470

[29] Mishra R. M., Rai J.S.P.: Polymer-Plastics Technology and Materials 2018, 58, 1. https://doi.org/10.1080/03602559.2018.1471716

[30] Sharma S., Singh A.A., Majumdar A., Butola B.S.: Journal of Materials Science 2019, 54, 8971. https://doi.org/10.1007/s10853-019-03521-9

[31] Sikora J.W., Gajdos I., Puszka A.: Polymers 2019, 11, 787. https://doi.org/10.3390/polym11050787

[32] Prashantha K., Lacrampe M.F., Krawczak P.: EXPRESS Polymer Letters 2011, 5, 295. http://dx.doi.org/10.3144/expresspolymlett.2011.30

[33] Kaygusuz I., Kaynak C.: Plastics, Rubber, and Composites 2015, 44, 41.
https://doi.org/10.1179/1743289814Y.0000000116

[34] Davachi S.M., Kaffashi B.: International Journal of Polymeric Materials and Polymeric Biomaterials 2015, 64, 497.

https://doi.org/10.1080/00914037.2014.977897

[35] Eryildiz M., Altan M.: Polymer Composites 2019, 41, 757. https://doi.org/10.1002/pc.25406

[36] Erpek C.E.Y., Ozkoc G., Yilmazer U.: Polymer Composites 2015, 37, 3134. https://doi.org/10.1002/pc.23511

[37] Vaia R.A., Giannelis E.P.: Macromolecules 1997, 30, 8000. https://doi.org/10.1021/ma9603488

[38] Tham W.L., Poh B.T., Ishak Z.A.M., Chow W.S.: Journal of Thermal Analysis and Calorimetry 2014, 118, 1639. https://doi.org/10.1007/s10973-014-4062-2

[39] Singla R.K., Maiti S.N., Ghosh A.K.: Journal of Materials Science 2016, 51, 10278.

https://link.springer.com/article/10.1007/s10853-0160255-3

Recceived 20 VIII 2021.

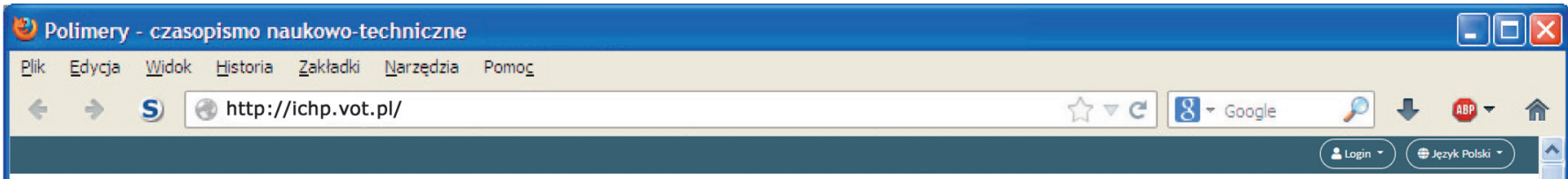

\section{POIIMIERY}

